\title{
PEMANFAATAN ALAT EVALUASI UNTUK MENINGKATKAN HASIL BELAJAR PADA MATERI APBN \& APBD SISWA KELAS XI IPA
}

\author{
Shafa Rizqi Nabilah¹, Waspodo Tjipto Subroto2, \\ Shafa.17080554020@mhs.unesa.ac.id12,waspodosubroto@unesa.ac.id22 \\ Program Studi Pendidikan Ekonomi, Universitas Negeri Surabaya ${ }^{1,2}$
}

\begin{abstract}
The purpose of this study is to analyze the differences in learning outcomes and to analyze the effectiveness of the use of evaluation tools on learning outcomes in State Expenditure Revenue Budget and Regional Expenditure Budget materials toward students in science class XI. Because there is a decrease in student learning outcomes during distance learning so that, this study utilizes experimental research that uses a nonequivalent control group design, with a population of 170 students with majors in Science. In selecting the sample, researcher uses purposive sampling technique with Science class XI 3 as the experimental class and Science class XI 4 as the control class, but the only difference in the experimental class is given as additional evaluation tools. This study utilizes hypothetical test of pre-test value and post-test with One Way Anova. Based on these results, in the use of evaluation tools there was no significant difference in student learning outcomes in State Expenditure Revenue Budget and Regional Expenditure Budget materials toward students in science class $\mathrm{XI}$ and the use of evaluation tools had effectiveness as a support for improving learning outcomes with State Expenditure Revenue Budget and Regional Expenditure Budget materials toward student ins science class XI
\end{abstract}

Keywords: learning outcome, evaluation tool, quizizz

\begin{abstract}
Abstrak
Tujuan dari penelitian ini ialah menganalisis perbedaan hasil belajar dan menganalisis efektivitas pemanfaatan alat evaluasi pada materi APBN \& APBD pada siswa kelas XI IPA.Karena terdapat penurunan hasil belajar peserta didik selama pembelajaran jarak jauh sehingga penelitian ini hendak memanfaatkan penelitian eksperimen yang menggunakan desain nonequivalent control group design. Penelitian mempunyai populasi sebanyak 170 peserta didik dengan jurusan MIPA. Dalam memilih sampel penelitian ini menggunakan teknik purposive sampling dengan sampel kelas XI MIPA 3 sebagai kelas eksperimen dan kelas XI MIPA 4 sebagai kelas kontrol. Hanya saja yang membedakan pada kelas eksperimen yang diberi tambahan alat evaluasi.Penelitian ini memanfaatkan uji hipotesis hasil pretest dan hasil posttest dengan One Way Anova. Hasil penelitian menjelaskan bahwa dalam pemanfaatan alat evaluasi tidak ada perbedaan yang signifikan terhadap hasil pada belajar peserta didik dalam materi pembelajaran APBN APBD kelas XI IPA dan pemanfaatan alat evaluasi mempunyai keefektivan sebagai pendukung peningkatan hasil belajar dengan materi APBN APBD pada kelas XI IPA
\end{abstract}

Kata Kunci: hasil belajar, alat evaluasi, quizizz

\section{PENDAHULUAN}

Pandemi corona disease menyebabkan pendidikan dan teknologi tidak dapat di pisahkan keberadaanya. Akibatnya selama selama pembelajaran jarak jauh hasil belajar peserta didik mengalami penurunan, sehinggaha lini segera ditindak lanjuti supaya peserta didik mampu meningkatkan kemampuan pada dirinya meskipun melakukkan proses pembelajaran secara online. Selaras dengan penelitian dari Prasetya \& Harjanto (2020) bahwasanya pembelajaran online sangat berpengaruhpositif 


\section{Efektor, Volume 8 Issue 2, 2021, Pages 142 -153 \\ Shafa Rizqi Nabilah, Waspodo Tjipto Subroto}

trhadap hasil belajar peserta didik. Menurut Indonesia (2003) Undang Undang No. 20 Tahun 2003, mengatur mengenai "sistem pendidikan nasional " pasal 31 ayat 2 berisi tentang Pendidikan jarak jauh ini merupakan sebuah pelayanan pendidikan yang dapat digunakan masyarakat yang kurang bisa mengimplementasikan pembelajaran secara tatap muka sehingga perlu adanya Internet Learning atau belajar secara online. Proses pembelajaran secara jarak jauh ini juga membutuhkan hasil belajar peserta didik yang diperoleh melalui kuis atau ujian. Selaras penelitian dari Adiwisastra (2015) bahwa peningkatan hasil belajar dapat diperoleh melalui pemanfaatan kuis. Hasil belajar tersebut merupakan capaian kemampuan dan pemahaman dari peserta didik. Karena evaluasi pembelajaran akan mempunyai hubungan dengan hasil belajar peserta didik (Arikunto, 2013:3). Selaras dengan penelitian dari Asy'ari (2000) bahwa hasil belajar merupakan sebuah capaian nilai tertinggi yang didapatkan oleh peserta didik selama melakukkan pembelajaran. Menurut Hamalik (2007) berpendapat bahwa hasil belajar tu merupakan karena adanya perubahan sikap oleh peserta didik yang diukur melalui komposisi nilai kognitif, afektif dan psikomotoriknya. Selain itu menurut Al Tabany (2014:13) bahwa hasil belajar mempunyai sifat komperehensif terdiri dari nilai kognitif,afektif, dan psikomotorik. Perolehan hasil dari belajar dapat didapatkan dari pelaksanaan ujian atau kuis yang diselenggarakan setelah proses pembelajaran guna meninjau capaian kognitif, afektif, hingga psikomotorik.

Proses pembelajaran terdiri dari penyampaian materi pembelajaran hingga evaluasi pembelajaran, rangkaian tersebut dapat efektif jika dimanfaatkanya tekhnologi sebagai pendukung pembelajaran misalnya internet (Munir, 2009) seperti dalam teori belajar Bhurrus Frederic Skinner pada buku Theories Of Learning menyatakan bahwa model pengajaran berbabasis komputer tidak hanya memiliki peran dalam penyajian materi saja, melainkan digunakan sebagai alat evaluasi yang dapat mendukung menganalisis perbandingan hasil dari belajar peserta didik. Didukung penelitian lain dari Chotimah (2018) yakni proses evaluasi pembelajaran akan berjalan efisien jika memanfaatkan pembelajaran berbasise-learning karena dapat di akses dimanapun peserta didik berada.

Berdasarkan Observasi pra penelitian yang telah di laksanakan di SMA Negeri 6 Surabaya, bahwa sudah menerapkan kurikulum 2013 dengan pembelajaran E-learning dengan pemanfaatan google classroom, google meet, whatsapp group, zoom dan web e-learning yang dimiliki oleh sekolah. Dalam pelaksanaan evaluasi baik latihan soal soal,ujian tengah semester atau ujan akhir semester, guru memanfaatkan google form sebagai media belajar yang langsung tersedia nilai saat peserta didik selesai dalam mengerjakan ujian. Berdasarkan wawancara dengan narasumber yakni guru pengampu ekonomi, ternyata terdapat penurunan hasil dari belajar peserta didik saat pelaksanaan pembelajaran jarak jauh ini. Selain itu berdasarkan wawancara selanjutnya pada peserta didik Kelas XI IPA 4 ternyata mereka mengeluhkan evaluasi pembelajaran yang membosankan pada evaluasi sebelumnya dengan menggunakan web learning yang tidak menarik. Sehingga menyebabkan penurunan hasil belajar peserta didik. Hal tersebut tidak bisa dibiarkan begitu saja dalam pelaksanaan pembelajaran jarak jauh. Meninjau Materi APBN APBD ini membutuhkan pemahaman teori yang tinggi serta wawasan mengenai pendapatan dan pengeluaran negara dan daerah yang luas sehingga perlu adanya media. Media merupakan penyajian informasi terhadap siswa guna penyajian materi ajar dengan membutuhkan alat maupun tidak (Fathurrohman, 2017:20). Latihan soal disajikan dengan menggunakan media yang bersifat kontiunitas agar hasil dari belajar siswa semakin baik. Alat evaluasi yang hendak digunakan adalah alat evaluasi quizizz. Dalam penerapan alat evaluasi tersebut diperlukan jaringan intenet yang stabil. Sehingga diharapkan dalam pemanfaatan alat evaluasi tersebut dapat meningkatkan hasil dari belajar peserta didik tersebut. Hal ini di didukung oleh penelitian dari Noor (2020) yang mana didapatkan peningkatan hasil belajar sebanyak $20 \%$ dengan pemanfaatan quizizz. Selain itu hasil penelitian lain dari Citra \& Rosy (2020) bahwasanya terdapat peningkatan hasil belajar dalam pemanfaatan quizizz

Jenis teknik evaluasi ada dua yakni tes tertulis dan tidak tertulis. Teknis tes terdiri dari penilaiaan sikap dan kepribadian siswa (Wulan \& Aristia, 2018). Sehingga dapat dimanfaatkan dalam pengukuran tingkat kemampuan peserta didik dengan pemanfaatan mendapatkan hasil belajar yang 


\section{Efektor, Volume 8 Issue 2, 2021, Pages 142 -153 \\ Shafa Rizqi Nabilah, Waspodo Tjipto Subroto}

tentunya dengan menggunakan alat evaluasi. Alat evaluasi yang digunakan pada saat pembelajaran jarak jauh adalah alat evaluasi yang berbasis teknologi. Alat evaluasi ini menyajikan beberapa soal atau kuis yang berisi materi mengenai pembelajaran pada proses belajar mengajar sebelumnya. Menurut Widiarsih (2020) mengungkapkan yakni alat evaluasi yang mampu menilai situasi dan kondisi siswa siswi pada proses pembelajaran merupakan alat evaluasi dikategorikan baik. Alat evaluasi ini juga dapat dikatakan sebagai instrumen evaluasi. Sehingga dapat mengevaluasi sesuai keadaan proses pembelajaran yang ada (Lubis, 2019). Berdasarkan Arifin (2020) menyatakan pendapatnya bahwa alat evaluasi hasil belajar merupakan kumpulan alat untu mengukur evaluasi, kunci jawaban dan panduan penilaianya. Alat evaluasi yang akan dimanfaatkan pada media belajar penelitian ini ialah alat evaluasi quizizz. Alat evaluasi quizizz ini dapat diakses secara gratis melalui media smartphone, laptop atau tablet dengan memasukkan kode permainan yang telah dibuat dan dibagikan oleh guru, quizizz ini dapat memberikan data statistik mengenai hasil belajar peserta didik yang dapat di unduh melalui microsoft excel (Suharsono, 2020). Selain itu menurut Rahman (2020) bahwa pemanfaatan aplikasi quizizz ini dapat meningkatkan minat dan motivasi mahasiswa dalam mengerjakan kuis.Selaras dengan pendapat Noor (2020) bahwa quizizz ini merupakan web tool pembelajaran yang menyenangkan, sehingga dapat menjadi instrumen penilaian yang berpengaruh pada hasil pembelajaran siswa. Melalui pemanfaatan alat evaluasi ini mempengaruhi pada peningkatan hasil belajar dan peningkatan minat dan motivasi siswa dalam mengerjakan proses evaluasi. Quizizz ini merupakan sebuah aplikasi media belajar yang dirancang menarik dengan fitur lagu dan gambar, sehingga menjadi sebuah tantangan yang dapat menguji kemampuan dari peserta didik. Semua peserta didik dapat bersaing dalam memperoleh nilai yang baik jika menjawab pertanyaan dengan benar dan tepat. Apalagi jika memilih pada kotak yang salah akan mengurangi nilai dari setiap pemain.

Berdasarkan pernyataan tersebut maka peneliti merumuskan tujuan pada penelitian yakni 1) Menganalisis perbedaan hasil pada belajar kelas yang memanfaatkan alat evaluasi dan kelas yang tidak memanfaatkan alat evaluasi ; 2) Menganalisis efektifitas pemanfaatan alat evaluasi quizizz pada materi APBN dan APBD terhadap hasil belajar.

\section{METODE PENELITIAN}

Penelitian ini yakni penelitian eksperimen. Menurut lkm \& Ugm (2011), berpendapat bahwa penelitian eksperimen merupakan penelitian yang menyajikan sebuah informasi mengenai tindakan yang hendak dilaksanakan peneliti terhadap subjek penelitianya. Penelitian eksperimen adalah penelitian yang menggunakan data dari sebuah variabel yang perlu dimanipulasi dengan adanya tindakan dari peneliti oleh subjek penelitian setelah itu diukur bagaimana dampak dari tindakan tersebut (Jaedun, 2011). Penelitian ini memanfaatkan desain nonequivalent control group design. Pemilihan desain tersebut dimanfaatkan untuk membedakan kelompok eksperimen dan kontrol. Terdapat beberapa tahapan dalam penelitian ini yakni 1 )planning/perencanaan, yang terdiri dari penyusunan modul pembelajaran mencakup silabus, rencana pelaksanaan pembelajaran (RPP) beserta lembar validasi rencana pelaksanaan pembelajaran,instrument penelitian beserta lembar validasi instrument penelitian, kisi kisi penulisan butir soal 2) Action/pelaksanaan yakni melaksanakan semua proses pembelajaranjarakjauhyang disesuaikan pada rencana pelaksanaan pembelajaran (RPP) 3) Observation/Pengamatan, yang dilaksanakan bersamaan pada proses pembelajaran jarak jauh berlangsung 4) Reflection/refleksi, peneliti bersama guru pengampu mata pelajaran berdiskusi bersama mengenai kelebihan dan kendala kendala yang menghambat proses pembelajarapesertadidikterutamapadaevaluasipembelajarandenganmenggunakanaplikasiquizizz

Berikut merupakan rancangan pada penelitian ini (Sugiyono, 2012 : 116):

\begin{tabular}{cccc}
01 & & $X$ & 02 \\
\hline & 03 & $X$ & 04
\end{tabular}




\author{
Keterangan \\ 01 : Pretest kelas eksperimen \\ $X$ : Perlakuan \\ O2: Postest kelas eksperimen \\ O3 : Pretest kelas kontrol \\ 04 : Postest kelas kontrol
}

Penelitian in memanfaatan populasi sebanyak 170 siswa siswi kelas XI SMA Negeri 6 Surabaya . Sampel yang dimanfaatkan sebanyak 72 peserta didik terbagi jadi dua sebagai kelompok eskperimen yakni kelas XI IPA 4 dan Kelompok Kontrol yakni kelas XI IPA 3. Digunakanya teknik purposive sampling, yang mana akan diambil dengan beberapa pandangan.

Instrumen pada penilaian adalah sebuah media yang digunakan untuk dicarinya data pada penilaian penelitian secara efektif. Jenis instrumen penelitian ini terdiri tes maupun non tes (Faruq \& Afiah, 2018). Instrumen penelitian berjumlah 20 butir soal,dengan 8 indikator yang mengandung soal pada materi APBN \& APBD. Untuk menguji kelayakan instrumen penilaian maka dilakukan analisis butir pada soal. Instrumen penelitian ini pada soal pretest dan posttest yang di buat dengan merujuk soal soal APBN APBD oleh buku ekonomi untuk SMA/MA kelas XI karangan Irim Rismi H.,Kartika S.,Yunita N. Dengan penerbit Intan Pariwara tahun 2019 ,soal oliempiade ekonomi mengenai APBN APBD yang telah diunggah di internet

\title{
HASIL DAN PEMBAHASAN
}

Penelitian ini sesuai dengan tahap tahap penelitian eksperimen yang telah di rancang sebelumnya. Tahapan pertama yakni planning atau perencanaan yakni penyusunan silabus, rencana pelaksanaan pembelajaran kelas control dan kelas eksperimen berserta lembar validasi , instrument penelitian pretest dan posttest kelas kontrol dan kelas eksperimen beserta lembar validasi dan terakhir yakni penyusunan kisi kisi butir soal.Setelah itumelaksanakan beberapa langkah pertimbangan sebelum melakukkan penelitian di dalam kelas, peneliti melakukkan penentuan kelas yang hendak dipakainya sebagai kelompok kontrol dan kelompok eksperimen. Sehingga peneliti membutuhkan dua kelas pada pelaksanaan penelitianya. Guru ekonomi lintas minat SMAN 6 Surabaya memberi saran kepada peneliti untuk memanfaatkan kelas XI IPA 3 sebagai kelompok kontrol dan kelas XI IPA 4 sebagai kelompok eksperimen .Selanjutnya peneliti melakukkan tes terkait hasil belajar dari kelas XI IPA 3 dan XI IPA 4 guna mengetahui kemampuan oleh kedua kelas tersebut dengan menggunakan tes homogenitas dan tes normalitas.

Pada uji kolmogorov smirnov pada tes normalitas memiliki hasil 0,200.Sehingga dapat dikatakan bahwa nilai tersebut $>0,05$, maka dari itu kelompok eksperimen dan kelompok kontrol dapat dikatakan lolos oleh uji normalitas serta mempunyai ditribusi normal. Selanjutnya pada uji homogenitas dengan digunakanya uji levene statistics pada kedua kelas tersebut menghasilkan nilai 0,118, yang menunjukkan $>0,05$.Sehingga kelas eskperimen dan kelas kontrol bisa di nyatakan lolos pada uji homogenitas dan mempunyai kesamaaan dalam kemampuan pada dua kelas tersebut. Sehingga pada penelitian ini digunakanya sampel penelitian terdiri dari peserta didik kelas XI IPA 3 yang mempunyai total sebanyak 34 siswa siswi dan 33 siswa siswi pada kelas XI IPA 4, yang mana kelas XI IPA 3 sebagai kelompok kontrol dan kelas XI IPA 4 sebagai kelompok eksperimen hendak akan memanfaatkan alat evaluasi quizizz.

Pada instrumen penelitian, dilakukkanya uji taraf kesukaran butir soal serta uji daya beda pada soal pretest dan soal posttest. Berikut merupakan tabel uji taraf kesukaran butir soal 
Tabel 1. Uji Taraf Kesukaran Butir Soal

\begin{tabular}{|l|l|l|}
\hline Kriteria & Nomor Soal & Jumlah \\
\hline Mudah & 19,26 & 2 \\
\hline Sedang & $\begin{array}{l}1,2,3,4,5,6,7,8,9,11,16,17,18,20,21, \\
22,23,24,25,27,28,30\end{array}$ & 22 \\
\hline Sukar & $12,13,14,29$ & 4 \\
\hline $\begin{array}{l}\text { Sangat } \\
\text { sukar }\end{array}$ & 10,15 & 2 \\
\hline Jumlah & & 30 \\
\hline
\end{tabular}

\section{Sumber : Data diolah peneliti(2021)}

Padatabel 1 dihasilkanbahawasanya dikategorikan terdapat 2 butir soal pada tingkat mudah , 22 butir soal pada tingkat sedang, 4 butir soal pada tingkat sukar dan 2 butir soal pada tingkat sangat sukar. Dilanjutkan dengan uji daya beda soal yang dimanfaatkan dalam perbedaan tingkatan kemampuan pada peserta didik. Berikut merupakan tabel dari uji daya beda soal

Tabel 2. Uji Daya Beda Butir Soal

\begin{tabular}{|l|l|l|l|}
\hline $\begin{array}{l}\text { Ketera } \\
\text { ngan }\end{array}$ & $\begin{array}{l}\text { Inde } \\
\text { ks } \\
\text { DP } \\
(\%)\end{array}$ & Nomor Soal & $\begin{array}{l}\text { Jum } \\
\text { ah }\end{array}$ \\
\hline $\begin{array}{l}\text { Sanga } \\
\text { t } \\
\text { Buruk }\end{array}$ & $\begin{array}{l}\text { Neg } \\
\text { atif- } \\
9 \%\end{array}$ & $5,9,12,14,15,20$ & 6 \\
\hline Buruk & $\begin{array}{l}10 \% \\
19 \%\end{array}$ & & \\
\hline $\begin{array}{l}\text { Sedan } \\
\text { g }\end{array}$ & $\begin{array}{l}20 \% \\
29 \%\end{array}$ & $1,2,7,10$ & 4 \\
\hline Baik & $\begin{array}{l}30 \% \\
-\end{array}$ & 22 & 1 \\
\hline $\begin{array}{l}\text { Sanga } \\
\text { t Baik }\end{array}$ & $\begin{array}{l}50 \% \\
\text { keat } \\
\text { as }\end{array}$ & $\begin{array}{l}3,4,6,8,11,13,16,17,18,19,21,2 \\
3,24,26,27,28,29,30\end{array}$ & 19 \\
\hline $\begin{array}{l}\text { Jumla } \\
\text { h }\end{array}$ & & & 30 \\
\hline
\end{tabular}

\section{Sumber : Data diolah peneliti(2021)}

Pada tabel 2 memaparkan hasil Uji daya beda soal yang dapat dikategorikan terdapat 6 butir soal dengan kategori sangat buruk , 4 butir soal kategori sedang, 1 butir soal kategori baik sedangkan 19 butir soal kategori sangat baik

Langkah Selanjutnya yaitu dilakukanya uji validitas pada butir soal yang hendak dimanfaatkan untuk pengukuran tingkat kevalidan setiap butir soal pada alat evaluasi guna diketahuinya hasil belajar peserta didik. Berikut merupakan tabel uji validitas butir soal :

Tabel 3. Uji Validitas Butir Soal

\begin{tabular}{|l|l|l|}
\hline Nomor Soal & Kriteria & Jumlah \\
\hline $\begin{array}{l}3,6,8,9,11,13,16,17,18,19,21 \\
22,23,24,25,26,27,28,29,30\end{array}$ & Valid & 20 \\
\hline $1,2,4,5,7,10,12,14,15,20$ & Tidak Valid & 10 \\
\hline
\end{tabular}

\section{Sumber : Data diolah peneliti(2021)}

Pada tabel 3 yakni tabel uji validitas butir soal yang mana dikategorikan 20 soal berkriteria valid dan 10 pada soal berkriteria tidak valid. Butir soal yang dinyatakan tidak valid tidak bisa dimanfaatkan dalam penelitian. Dilanjutkan dengan uji realibilitas butir pada soal yang guna untuk diukurnya konsistensi instrumen ketika digunakan sebagai alat evaluasi. Berikut merupakan tabel uji realibiltas butir soal 
Efektor, Volume 8 Issue 2, 2021, Pages 142 -153

Shafa Rizqi Nabilah, Waspodo Tjipto Subroto

Tabel 4. Uji Realibilitas Butir Soal

\begin{tabular}{|c|c|}
\hline Guttman Split-Half Coefficient & .282 \\
\hline
\end{tabular}

\section{Sumber: Data diolah peneliti(2021)}

Tabel 4 merupakan tabel uji realibilitas butir soal yang mana menjelaskan bahwa uji Gutmman Split -Half Coeffiecient sebesar 0,282, sehingga uji realibilitas di kategorikan mempunyai realibilitas yang rendah untuk mengukur hasil belajar pada materi APBN\&APBD.

Tahap penelitian eksperimen selanjutnya yakni tahap pelaksanaan penelitian yakni dengan melaksanan seluruh kegiatan pembelajaran jarak jauh sesuai dengan rencana pelaksanaan pembelajaran yang telah disusun,peneliti menginstruksikan kepada peserta didik mengenai langkah -langkah dalam mengerjaka nevaluasi pembelajaran ,peserta didik mempunyai durasi 60 detik dalam setiap butir soal , jika terdapat 20 butir soal maka keseluruhan durasi menyelesaikan 20 butir soal ialah 20 menit untuk pretest dilanjut dengan materi pembelajaran APBN \& APBD dan terakhir adalah mengerjakan posttest dengan durasi waktu 20 menit juga. Sehingga menghasilkan hasil belajar peserta didik yang akan di telititi oleh peneliti untuk mengetahui perbedaan dalam pemanfaatan alat evaluasi quizizz pada kelas control dan eksperimen. Hasil data uji eksperimen pada penelitian ini di awali dengan uji normalitas. Berikut merupakan uji pada normalitas dengan aplikasi SPSS versi 20

Tabel 5. Uji Normalitas Pada Kelas Eksperimen

\begin{tabular}{|l|l|}
\hline Hasil & $\begin{array}{l}\text { Shapiro } \\
\text { Wilk }\end{array}$ \\
\hline Pre Test & 0,044 \\
\hline Post Test & 0,260 \\
\hline
\end{tabular}

Sumber : Data diolah peneliti(2021)

Tabel 6. Uji Normalitas Pada Kelas Kontrol

\begin{tabular}{|l|l|}
\hline Hasil & $\begin{array}{l}\text { Shapiro } \\
\text { Wilk }\end{array}$ \\
\hline Pre Test & 0,266 \\
\hline Post Test & 0,168 \\
\hline
\end{tabular}

\section{Sumber : Data diolah peneliti(2021)}

Uji normalitas atau disebut uji distribusi normal, sebagai pengukur data penelitian apakah data tersebut benar terdistribusi normal atau tidak normal (Square, 2017). Padatabel 5 yakni hasil uji normalitas pada kelas eksperimen pada penelitian menjelaskan yakni kelompok eksperimen mempunyai hasil normalitas sebesar 0,044 pada pretest dan 0,260 pada posttest. Sehingga hasil uji normalitas pada pre test tidak berdistribusi normal karena $<0,05$ dan berdistribusi normal pada posttest karena mempunyai hasil uji normalitas $>0,05$.

Padatabel 6 yakni hasil uji normalitas pada kelas control menjelaskan bahwasanya Kelompok kontrol mempunyai hasil uji normalitas yaitu 0,266 pada pretest dan 0,168 hasil posttest. Hasil uji normalitas pada pretest dan posttest dapat dikatakan berdistribusi normal karena mempunyai hasil < 0,05 . 
Dilanjutkan dengan uji homogenitas yang memiliki tujuan untuk disajikanya varians data pada penelitian dengan melihat uji levene's test for equality of variance

Tabel 7. Uji Homogenitas Pretest Pada Kelas Eksperimen \& Kontrol

Test of Homogeneity of Variance
\begin{tabular}{|l|r|c|c|c|}
\hline & Levene Statisic & dfi & \multicolumn{1}{c|}{ dR } & \multicolumn{1}{c|}{ Sig. } \\
\hline Based on Mean & 3.259 & 1 & 66 & 076 \\
\hline
\end{tabular}

\section{Sumber : Data diolah peneliti(2021)}

Tabel 8. Uji Homogenitas Posttest Pada Kelas Eksperimen \& Kontrol

\begin{tabular}{|l|r|c|c|c|} 
Test of Homogeneity of Variance \\
\hline & Levene Staisfic & df1 & \multicolumn{1}{c|}{ dr } & \multicolumn{1}{c|}{ Sig. } \\
\hline \hline Based on Mean & .000 & 1 & 66 & .994 \\
\hline
\end{tabular}

Sumber : Data diolah peneliti (2021)

Tabel 7 yakni hasil uji homogenitas pretest pada kelas eksperimen \& control yang telah disajikan, maka dapat diketahui signifikansi kelompok eksperimen dan kelompok kontrol pada nilai pre test adalah 0,076 >0,05, bahwa dua kelas tersebut mempunyai varians homogen sama. Sedangkan pada tabel 8 yakni hasil uji homogenitas posttest pada kelas eksperimen \& control memaparkan bahwa signifikansi pada kelompok eksperimen dan kelompok kontrol pada nilai posttest adalah 0,994 $>0,05$. Maka dari itu, disimpulkan bahwa kedua kelompok tersebut mempunyai varians homogen sama dan tidak mempunyai beda yang signifikan antara kedua kelompok tersebut. Dilanjutkan oleh Uji One Way Annova

Tabel 9. Uji One Way Annova Pretest Pada Kelas Eksperimen \& Kontrol

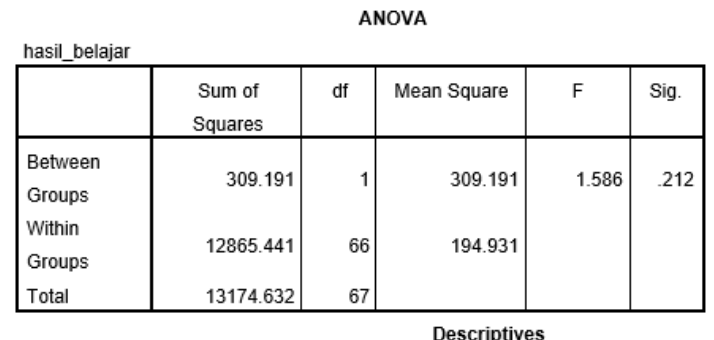

hasil_belajar

\begin{tabular}{|l|r|r|r|r|}
\hline & \multicolumn{1}{|c|}{ N } & \multicolumn{1}{c|}{ Mean } & \multicolumn{1}{c|}{ Minimum } & Maximum \\
\hline pre eks & 34 & 59.5588 & 20.00 & 80.00 \\
pre control & 34 & 55.2941 & 30.00 & 80.00 \\
Total & 68 & 57.42645 & 20.00 & 80.00 \\
\hline
\end{tabular}

Sumber : Data diolah peneliti(2021)

Tabel 9 yakni uji one way annova pretest pada kelas eksperimen \& kontrol yang menghasilkan nilai 309.191 menunjukkan bahwa terdapat varians antar kelompok sehingga terdapat beda antar nilai variabel bebas sedangkan jika varians kelompok menunjukkan nilai 12865.441 yang menunjukkan tidak adanya perbedaaan varian dalam sebuah kelompok. 194.931 menunjukkan nilai pada rata rata dalam kelompok. Sedangkan rata rata diantara kelompok menunjukkan nilai 385,941.

Tahap penelitian eksperimen selanjutnya yakni tahap pengamatan yang mana peneliti mengamati proses evaluasi yang telah dilakukkan berdampak atau tidak dengan adanya pemanfaatanalat evaluasi quizizz pada kelas eksperimen dan tidak menggunakan alat evaluasi quizizzp 
adakelas kontrol. Didukung dengan data nilai $F$ hitung sebesar 1,586 dengan signifikansi 0,212 sehingga dapat dikatakan $>0,05$. Maka nilai $F$ hitung tersebut dinyatakan tidak signifikan. Dari Hasil ditunjukkan bahwa nilai posttest kelas eksperimen dan kelas kontrol mempunyai nilai yang tidak jauh signifikan perbedaanya.

\section{Tabel 10. Uji One Way Annova Posttest Pada Kelas Eksperimen \& Kontrol}

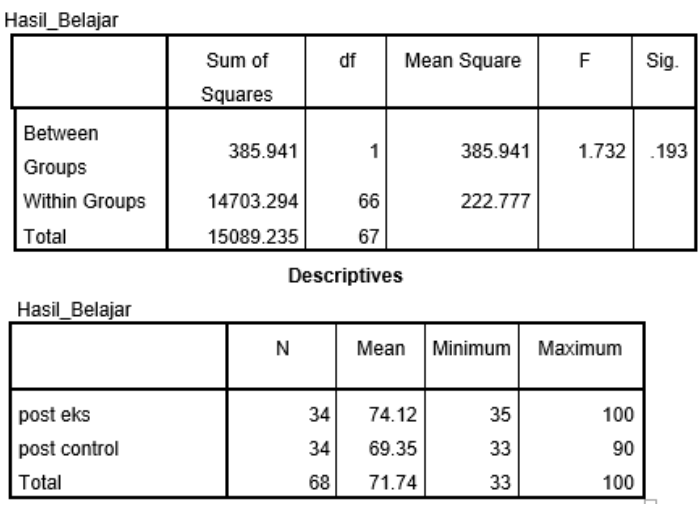

Sumber : Data diolah peneliti(2021)

Tabel10 yakni hasiluji one way annova posttest pada kelas eksperimen\&control menjelaskan mengenai hasil posttest pada uji one way anova. Nilai 385.941 menunjukkan bahwa terdapat varians antar kelompok sehingga memiliki beda antara nilai variabel bebas sedangkan jika varians kelompok menunjukkan nilai 14703.294 yang menunjukkan tidak adanya perbedaan varian dalam sebuah kelompok. Sedangkan nilai 222,777 menunjukkan rata rata dalam kelompok. Rata rata diantara kelompok menghasilkan nilai sebesar 385,941.

Selanjutnya nilai $F$ hitung adalah 1,732 dengan signifikansi 0,193 sehingga dapat dikatakan $>0,05$. Maka nilai $F$ hitung tersebut dinyatakan tidak signifikan. Hasil menunjukkan bahwa nilai posttest kelas eksperimen dan kelas kontrol mempunyai nilai yang tidak jauh signifikan perbedaanya, dengan pembuktian bahwa nilai rata rata hasil post test kelas eksperimen adalah 74,12 dan nilai rata rata hasil post test kelas kontrol adalah 69,35. Yang mana akan diperkuat dengan uji N-Gain dibawah ini

\section{Tabel 11. Uji N - Gain}

\begin{tabular}{|l|l|l|l|}
\hline $\begin{array}{c}\text { Kelas } \\
\text { Eksperimen }\end{array}$ & \multicolumn{1}{|c|}{ Nilai } & \multicolumn{1}{|c|}{$\begin{array}{c}\text { Kelas } \\
\text { Kontrol }\end{array}$} & \multicolumn{1}{|c|}{ Nilai } \\
\hline Minimal & -50 & Minimal & -25 \\
\hline Maximal & 1.00 & Maximal & 0.80 \\
\hline Rata Rata & 0,3291 & Rata Rata & 0,3024 \\
\hline
\end{tabular}

\section{Sumber : Data diolah peneliti(2021)}

Tabel 11 merupakanhasil uji $n$ - gain nilai rata rata kelas eksperimen sebesar 0,3291 dapat dikategorikan nilai tersebut kurang efektif sehingga pada proses pembelajaran dengan materi APBN APBD di kelas eksperimen dirasa juga kurang efektif.

Pada kelas kontrol mempunyai nilai rata rata sebesar 0,3024 yang dapat dikategorikan bahwa nilai tersebut dinyatakan kurang efektif juga. Sehingga dapat disimpulkan bahwasanya pada uji n-gain kedua kelas tersebut kurang begitu efektif pada proses implementasinya sehingga berdampak pada hasil belajar. Diperolehlah rata rata hasil pretest dan posttest kelas eksperimen dan kelas kontrol sebagai berikut. 
Efektor, Volume 8 Issue 2, 2021, Pages 142 -153

Shafa Rizqi Nabilah, Waspodo Tjipto Subroto

Tabel 12. Rata Rata Hasil Pretest dan Posttest Kelas Eksperimen dan Kelas Kontrol

\begin{tabular}{|l|l|l|l|}
\hline Kelas & $\begin{array}{l}\text { Hasil } \\
\text { Rata } \\
\text { Rata } \\
\text { pre } \\
\text { test }\end{array}$ & $\begin{array}{l}\text { Hasil } \\
\text { Rata } \\
\text { Rata } \\
\text { posttest }\end{array}$ & $\begin{array}{l}\text { Presentasi } \\
\text { kenaikan } \\
\text { pretest dan } \\
\text { posttest }\end{array}$ \\
\hline eksperimen & 59,6 & 73,4 & $23,15 \%$ \\
\hline Kontrol & 55,3 & 69,4 & $25,4 \%$ \\
\hline
\end{tabular}

Sumber : Data diolah peneliti(2021)

Dari tabel 12 diatas dapat diketahui bahwa hasil penelitian pada kelas eksperimen dan kontrol yang mana terdapat rata rata kenaikan pretest dan posttest. Rata Rata hasil pretest kelas eksperimen adalah 59,6 serta rata rata posttest kelas eksperimen adalah 73,4 . Sehingga dicapainya kenaikan sebesar 13.8 dengan prosentase $23,15 \%$. Sedangkan rata rata pada hasil pretest kelas kontrol 55,3 serta rata rata posttest kelas kontrol adalah 69,4 yang memeperoleh kenaikan 14,1 dengan prosentase $25,4 \%$.Kesimpulanya adalah terdapat perbedaan kenaikan hasil belajar karena pemanfaatan media belajar pada kelas kontrol dan kelas eksperimen, meskipun terlihat kelas kontrol memiliki kenaikan yang lebih tinggi daripada kelas eksperimen dengan selisih 0,3.Tahap penelitian yang terakhir yakni merupakan tahap refleksi yaitu peneliti bersama guru pengampu mata pelajaran mengevaluasi kelebihan dari pemanfaatan alat evaluasi quizizz yakni peserta didik lebih antusias dalam proses evaluasi. Selain itu tedapat kendala dalam proses pembelajaran seperti kurang lancarnya koneksi internet peserta didik sehingga menghambat dalam poses evaluasi. Selain itu peneliti dan guru hanya bisa menerima hasil belaja rpeserta didik tanpa melihat proses evaluasi secara langsung.

\section{Perbedaan Hasil Belajar Pada Kelas yang Menggunakan Alat Evaluasi dan Kelas yang Tidak Menggunakan Alat Evaluasi}

Media belajar quizizz ini digunakan oleh peneliti sebagai alat evaluasi bagi peserta didik karena dapat mengetahui perbedaan hasil belajar peserta didik. Peneliti menggunakan durasi waktu 60 detik pada setiap butir soal yang akan di kerjakan oleh peserta didik. Dalam proses pelaksanaan evaluasi tersebut. Selain membutuhkan konsentrasi yang tinggi dalam memahami tiap butir soal, peserta didik juga dituntut untuk berpikir secara cepat dan tepat mengingat durasi waktu pengerjaan terus berjalan. Peserta didik juga mendapatkan beberapa bonus yang ditawarkan oleh quizizz seperti penambahan durasi waktu, pengulangan dalam mengerjakan soal yang kurang benar atau bantuan dalam memilih jawaban dengan dihanguskanya opsi salah satu pilihan jawaban yang tidak tepat. Quizizz ini mempunyai manfaat dalam mengombinasikan pembahasan materi dan evaluasi yang berbasis permainan (Legaki et al., 2020). Selain itu menurutnya bahwa game yang mempunyai daya tarik yang menantang untuk digunakan dalam mendukung pembelajaran peserta didik (Legaki et al., 2020). Quizizz ini memiliki kelebihan dalam fitur fitur sebagai pendukungnya, seperti terdapat audio dengan suasana tegang, menantang saat proses mengerjakan evaluasi ditambah dengan rentang waktu terbatas yang telah ditentukan guru, selain itu juga terdapat gambar yang menarik sebagai latar belakang quizizz ini serta menyajikan hasil belajar yang muncul setelah peserta didik selesai dalam mengerjakan. Berdasarkan hasilnya, penelitian eksperimen ini menggunakan dua kelas yakni kelas eksperimen dan kelas kontrol. Bedanya, kelas eksperimen diberi perlakuan tambahan yakni pemanfaatan alat evaluasi quizizz. Hasil menyatakan bahwasanya nilai tes dari kelas eksperiman dan kelas kontrol mempunyai distribusi normal serta memiliki varians yang bersifat homogen. Dilanjutkan dengan uji one way annova yang menyatakan bahwa tidak ada pengaruh pemanfaatan alat evaluasi terhadap hasil belajar kelas eksperimen maupun kelas kontrol. Selain itu, menurut hasil uji n-gain adalah nilai rata rata kelas kelas eksperimen dikategorikan kurang efektif. 


\section{Efektor, Volume 8 Issue 2, 2021, Pages 142 -153 \\ Shafa Rizqi Nabilah, Waspodo Tjipto Subroto}

Pemanfaatan alat evaluasi quizizz ini tidak ada perbedaan hasil belajar yang signifikan antara kelas eksperimen yang menggunakan alat evaluasi quizizz dan kelas kontrol yang tidak menggunakan alat evaluasi quizizz. Karena berdasarkan observasi, pemanfaatan alat quizizz ini sudah pernah diimplementasikan pada materi sebelumnya. Selaras dengan penelitian dari Berdasarkan penelitian dari Aini (2019) yang mengungkapkan bahwa pemanfaatan media pembelajaran quizizz sebagai media belajar bahasa peserta didik di Bengkulu belum terimplementasi dengan baik karena banyak yang masih awam dengan alat evaluasi tersebut. Didukung kembali penelitian dari Dyah (2019) bahwasanya dalam pemanfaatan alat evaluasi quizizz ini tidak ada beda yang signifikan pada hasil belajar peserta didik. Sama halnya dengan penelitian dari Maulyda (2020) yang mengungkapkan bahwa hasil belajar dengan memanfaatkan alat evaluasi quizziz ini kurang begitu dibuktikan dengan tidak ada perbedaan rata rata skor hasil belajar pada kelas yang menggunakan quizizz maupun tidak yang menggunakan quizizz. Berdasarkan penelitian, proses evaluasi pada kelas eksperimen yang diberi perlakuan dengan adanya pemanfaatan alat evaluasi quizizz dan kelas yang tidak ada pemanfaatan alat evaluasi, tidak mempunyai perbedaan hasil belajar. Dikarenakan proses evaluasi ini dilakukkan secara jarak jauh, sehingga sulit dalam mengondisikan kelas. Disimpulkan bahwa dalam pemanfaatan alat evaluasi quiziz tidak ada perbedaan yang signifikan terhadap hasil belajar peserta didik dalam materi APBN APBD kelas XI IPA

\section{Efektifitas pemanfaatan alat evaluasi untuk meningkatkan hasil belajar}

Penelitian ini menggunakan jenis penelitian eksperimen dengan metode penelitian kuantitatif. Purposive sampel menjadi teknik sampel yang digunakan oleh peneliti. Butir Soal yang digunakan peneliti sebagai instrumen dalam penelitian ini adalah 20 dari 30 butir soal yang digunakan dalam mengukur hasil belajar peserta didik. Sehingga 10 butir soal dinyatakan tidak layak digunakan. Terlihat dari hasil belajar yang telah di peroleh, maka Indikator yang sangat dominan adalah indikator keenam dari 8 indikator total keseluruhanya. Indikator keenam berisi menjelaskan tujuan APBD. Pada indikator ini terdapat 3 butir soal didalamnya,indikator ini cenderung memahami tujuan APBD. Sedangkan untuk indikator keempat yaitu Mengetahui dan menjelaskan jenis pendapatan dan pengeluaran negara. Pada indikator tersebut peserta didik banyak mendapat jawaban yang kurang benar karena peserta didik kesulitan dalam memahami soal dengan ketentuan waktu yang terbatas pada setiap soal.

Berdasarkan hasil rata rata nilai posttest kelas kontrol dan kelas eksperimen, nilai rata rata hasil posttest kelas eksperimen adalah 73,4 terdapat peningkatan dari hasil pretest yakni sebesar 59,6. Sedangkan nilai rata rata hasil posttest kelas kontrol adalah 69,4 juga terdapat peningkatan dari hasil pretest yakni 55,3 . Seperti halnya terdapat perbedaan hasil belajar dari kelas eksperimen sebesar 85,3 dan kelas kontrol sebesar 80,7 . Selaras dengan penelitian pada siswa siswi kelas X SMK Ketintang Surabaya mempunyai hasil terdapat keefektifan dalam peningkatan hasil belajar pada mata pelajaran OTKP dengan pemanfaatan games quizizz. (Citra \& Rosy, 2020). Didukung dengan penelitian lain pada siswa SMP yang hasilnya terdapat keefektifan dalam peningkatan hasil belajar peserta didik dalam pemenafaatan alat evaluasi quizizz. (Kumalasari, 2020)

Berdasarkan observasi oleh peneliti, bahwa proses pembelajaran yang terjadi terdapat kekurangan. Yakni alat evaluasi quizizz membutuhkan jaringan internet yang stabil, sehingga beberapa peserta didik yang kurang menjangkau dalam jaringan internet akan susah dalam pelaksanaan proses evaluasi. Selain itu, penelitian ini dilakukkan secara jarak jauh. Karena adanya pandemi covid-19. Sehingga peneliti kesulitan dalam mengawasi peserta didik untuk melakukkan proses evaluasi dengan pemanfaaatan alat evaluasi quizizz. Proses evaluasi membutuhkan waktu untuk mengerjakan sangat terbatas yakni 20 menit untuk menyeleseikan keseluruhan butir soal. Sedangkan 40 menit digunakan untuk pemaparan materi pembelajaran. Selain itu alat evaluasi quizziz ini juga memiliki keunggulan yakni penampilan alat evaluasi yang sangat menarik dan membuat peserta didik interaktif dalam mengerjakan ujian (Handoko et al., 2021). Quizizz mendukung proses evaluasi yang akan di laksanakan oleh guru, serta mengatasi kejenuhan oleh peserta didik terhadap evaluasi menggunakan 


\section{Efektor, Volume 8 Issue 2, 2021, Pages 142 -153 \\ Shafa Rizqi Nabilah, Waspodo Tjipto Subroto}

kertas. Berdasarkan observasi, peserta didik yang memanfaatkan alat evaluasi lebih sungguh sungguh dalam menjawab butir soal yang telah diberikan karena jika salah dalam memilih opsi jawaban maka akan mengurangi poin dalam permainan, sehingga mengakibatkan hasil belajarnya menurun. Alat evaluasi quizizz merupakan media belajar bebrbasis online yang efektif dalam peningkatan hasil belajar. Dapat disimpulkan bahwa terdapat perbedaan efektivitas antara kelas yang memanfaatkan alat evaluasi quizizz dengan kelas yang tidak memanfaatakan alat evaluasi quizizz ditinjau dari peningkatan hasil pre test terhadap hasil post test pada kelas yang melakukkan pemanfaatan alat evaluasi. Sehingga alat evaluasi quizizz ini mempunyai keefektivan sebagai pendukung peningkatan hasil belajar dengan materi APBN APBD pada kelas XI IPA.

\section{SIMPULAN}

Dari pernyataan diatas maka dapat disimpulkan bahwa melalui penerapan pemanfaatan alat evaluasi quizizz selama proses pembelajaran jarak jauh tidak ada perbedaan dalam hasil belajar peserta didik pada materi APBN \& APBD siswa kelas XI IPA. Sedangkan pada efektifitas pemanfataan alat evaluasi quizizz ini berdampak positif ditinjau dari hasil rata rata nilai pre test dan posttest kelas eksperimen lebih tinggi daripada nilai pretest dan nilai posttest kelas kontrol. Dari hasil penelitian diatas maka saran yang diberikan oleh peneliti adalah perlu adanya penelitian kembali setelah pandemi corona disease berakhir. Supaya hasil penelitian lebih efektif, efisien, dan akurat. Selain itu dalam pemanfaatan alat evaluasi quizizz maka perlu adaya modifikasi model pembelajaran yang lebih menarik dan perlu dilakukan penelitian lebih lanjut dengan materi yang berbeda sehingga peserta didik lebih semangat dalam melaksanakan proses evaluasi.

\section{DAFTAR RUJUKAN}

Adiwisastra, M. F. (2015). Perancangan Game Kuis Interaktif Sebagai Multimedia Pembelajaran Drill and Practice Untuk. Jurnal Informatika., II(1), 205-211.

https://repository.widyatama.ac.id/xmlui/bitstream/handle/123456789/9018/Bab 2.pdf?sequence $=10$

Aini, Y. I. (2019). Pemanfaatan Media Pembelajaran Quizizz Untuk Pembelajaran Jenjang Pendidikan Dasar Dan Menengah Di Bengkulu. Jurnal Kependidikan, 2(25), 1-6.

Al Tabany, T. (2014). Mendesain Model Pembelajaran Inovatif,Progresif,Dan Kontekstual.

Arifin, Z. (2020). Zainal Arifin, . 20-59.

Arikunto, S. (2013). Dasar Dasar Evaluasi Pendidikan (2nd ed.).

Asy'ari, H., Andhini, N. F., li, B. A. B., Saintifik, A. P., Saintifik, P. P., Teori, A. K., \& Belajar, H. (2000). BAB II KAJIAN TEORI A. Hasil Belajar 1. Journal of Chemical Information and Modeling, 53(september 2016), 12-36.

Chotimah, K. (2018). Pelaksanaan Evaluasi Pembelajaran Melalui E-Learning Di Sekolah Indonesia Kota Kinabalu (SIKK) Malaysia. 29-30.

Citra, C. A., \& Rosy, B. (2020). Keefektifan Penggunaan Media Pembelajaran Berbasis Game Edukasi Quizizz Terhadap Hasil Belajar Teknologi Perkantoran Siswa Kelas X SMK Ketintang Surabaya. Jurnal Pendidikan Administrasi Perkantoran (JPAP), 8, 261-272. https://journal.unesa.ac.id/index.php/jpap/article/view/8242/4081

Dyah Kusumawati, S. (2019). EQUILIBRIA PENDIDIKAN Jurnal IImiah Pendidikan Ekonomi. Equilibria Pendidilan, 4(5), 36-46. http://journal.upgris.ac.id/index.php/equilibriapendidikan

Faruq, I. A. F., \& Afiah, A. R. (2018). Instrumen Penilaian Berbagai Kompetensi Atau Indikator Dalam Pencapaian Hasil Belajar SD / MI. Pendidikan Dasar, 152071200010.

Fathurrohman, M. (2017). Model Model Pembelajaran Inovatif.

Hamalik, O. (2007). Omear Hamalik, Proses Belajar Mengajar, (Jakarta: Bumi Aksara, 2007), HIm 30 2Dimyati Dan Mudjiono, Belajar Dan Pembalajaran, (Jakarta: Rineka Cipta Tahun2009), HIm $2001.15-49$. 
Efektor, Volume 8 Issue 2, 2021, Pages 142 -153

Shafa Rizqi Nabilah, Waspodo Tjipto Subroto

Handoko, W., Mizkat, E., Nasution, A., Hambali, \& Eska, J. (2021). Gamification in Learning using Quizizz Application as Assessment Tools. Journal of Physics: Conference Series, 1783(1), 012111. https://doi.org/10.1088/1742-6596/1783/1/012111

Ikm, P., \& Ugm, F. K. (2011). Penelitian Eksperimen Penelitian Eksperimen. 1-38.

Indonesia, R. (2003). UNDANG-UNDANG REPUBLIK INDONESIA NOMOR 20 TAHUN 2003 TENTANG SISTEM PENDIDIKAN NASIONAL.

Jaedun, A. (2011). Oleh : Amat Jaedun. Metodologi Penelitian Eksperimen, 0-12.

Kumalasari, V. V. (2020). Efektivitas Pembelajaran Daring Bahasa Jawa Menggunakan Google Kelas dan Quizizz Pada Siswa SMP Negeri 1 Kayen. Piwulang : Jurnal Pendidikan Bahasa Jawa, 8(2), 164-175. https://doi.org/10.15294/piwulang.v8i2.42488

Legaki, N. Z., Xi, N., Hamari, J., Karpouzis, K., \& Assimakopoulos, V. (2020). The effect of challengebased gamification on learning: An experiment in the context of statistics education. International Journal of Human Computer Studies, 144(June). https://doi.org/10.1016/j.jijcs.2020.102496

Lubis, E. (2019).PRINSIP_DAN_ALAT_EVALUASI_docx.

Maulyda, M. A., Rosyidah, A. N. K., Apsari, R. A., FR, A. F. U., \& Witono, A. H. (2020). Penggunaan Website Quizizz Untuk Mengevaluasi Hasil Belajar Calon Guru Sekolah Dasar. Fundamental Pendidikan Dasar, 3(2), 139-144.

Munir. (2009). Pembelajaran Jarak Jauh.

Noor, S. (2020). 済無No Title No Title. Journal of Chemical Information and Modeling, 53(9), 16891699. https://doi.org/10.1017/CBO9781107415324.004

Prasetya, T. A., \& Harjanto, C. T. (2020). Pengaruh Mutu Pembelajaran Online Dan Tingkat Kepuasan Mahasiswa Terhadap Hasil Belajar Saat Pandemi. Jurnal Pendidikan Teknologi Dan Kejuruan, 17(2), 188-197.

Rahman, R., Kondoy, E., \& Hasrin, A. (2020). Penggunaan Aplikasi Quizziz Sebagai Media Pemberian Kuis Dalam Meningkatkan Motivasi Belajar Mahasiswa. JISIP (Jurnal IImu Sosial Dan Pendidikan), 4(3), 60-66. https://doi.org/10.36312/jisip.v4i3.1161

Square, C., Of, G., \& Tes, F. (2017). Cara Membaca Angka. 0-4.

Sugiyono. (2012). No Title.

Suharsono, A. (2020). Journal 0 Ntn'l. 6356, 60-66. https://doi.org/10.31764/paedagoria.v11i1.1915

Widiarsih, T. (2020). Alat Evaluasi Pembelajaran. In Kumpulan Makalah. http://makalahbukanmasalah.blogspot.com/2015/09/alat-evaluasi-pendidikan.html

Wulan, A. H. Z., \& Aristia, R. (2018). Jenis - Jenis Instrumen dalam Evaluasi Pembelajaran. Universitas Muhammadiyah Sidoarjo, 1-13. http://eprints.umsida.ac.id/4050/1/Evaluasi pembelajaran Adea_Risa-1.pdf 